\title{
Screendance: The Aesthetics of Ironic Consciousness
}

\author{
Virginia Piper
}

$\prod^{0}$

osalind Krauss's 1976 article, "Video: The Esthetics of Narcissism" seeks to determine the particular kind of aesthetic experience made available by the then novel technology (or apparatus) of video. The article draws from psychoanalysis and semiotics in order to dematerialize the medium of film to then rematerialize it as the medium of the self in communication with itself, the medium of narcissism. While the technological apparatus in question now seems rather quaint in comparison with the innumerable advances in film and other visual media over the last forty years, the imperative to carefully consider the aesthetics of video, film, and the screen has yet to lose its urgency, most particularly in connection to screendance. Indeed, as Douglas Rosenberg wrote in 2006, evaluating the state of screendance, "we have not made the effort to begin to parse screendance into frames of reference as other art forms have done... Creating frames of reference and prisms through which a work of art is viewed, elevates the work of art by inserting it into an ongoing dialog with other work and also, perhaps more importantly, encourages the kind of metaphor, allusion and referencing that is the lifeblood of art in general."1 Krauss's consideration of the aesthetics of video in 1976 provides a timely opportunity for scholars and practitioners in 2011 to consider the particular aesthetic experience made possible by screendance.

Aesthetics carries along with it the albatross of an allegedly obfuscating discourse and of a failed utopianism. Over the past four decades, the aesthetic has increasingly come under attack as an obtrusive mediation of the relationship between text and reader, beholder and beheld. As Jacques Rancière scathingly summarizes: "Aesthetics came to be seen as the perverse discourse which bars this encounter and which subjects works, or our appreciations thereof, to a machine of thought conceived for other ends: the philosophical absolute, the religion of the poem, or the dream of social emancipation." ${ }^{2}$ Yet, as he points out, aesthetics is not a discipline so much as a "regime of identification," that which renders it possible to identify art as such, the mechanism of its very autonomy. And it is this autonomy, I would argue, that was at stake in Krauss's intervention in 1976 and remains troublesome in current discussions of screendance.

Autonomy, the inevitable, if not precarious, by-product of aesthetic discourse, seeks to draw distinctions and delimit boundaries between art and non-art (or to quell the sibling rivalry of the sister arts) as it registers the anxieties over the increasing commodification and concomitant fetishism in the art world. If, in seeking to name and describe the aesthetics of video, Krauss simultaneously seeks to establish its autonomy within the arts, her turn to the market undertakes a similar project in relation to commodity culture. She nervously asserts that the art world "has been deeply and disastrously affected by its relation to mass-media. That an artist's work be published, reproduced, and disseminated through the media has become, for the generation that has matured in the course of the last decade, virtually the 
only means of verifying its existence as art." This evaluation echoes Rosenberg's more recent assessment that "When we think about screendance, much less comes to mind in regard to the delineation of movements or genres within the field of practice. And identifiable authorship is quite rare. This lack of self-definition is cause for concern in a field that teeters on marginality."4 Aesthetics is what allows us to recognize art as such. The autonomy of screendance, as a field of practice and an artistic form, depends upon and calls for an elaboration of its aesthetics — as an art form and as a distinct practice.

Although Krauss does not turn toward the market and the bugbear of commodification until the very end of her article, the impulse towards autonomy is woven though the discussion of subjectivity and the creation of an autonomous self. For Krauss, video is the medium of narcissism, "an aesthetic mode by which the self is created through the electronic device of feedback." "Feedback" materialized in the apparatus of the camera and the monitor, comes to be synonymous with "mirroring," "echoing," "boomeranging," "doubling back," and, significantly, "dédoublement." Krauss suggests that "One could say that if the reflexiveness of modernist art is a dédoublement or doubling back in order to locate the object (and thus the objective conditions of one's experience), the mirror-reflection of absolute feedback is a process of bracketing out the object." ${ }^{\prime \prime}$ This dédoublement is the very condition that Paul de Man, drawing from Charles Baudelaire describes as "irony." Indeed, there is an eerie symmetry between Krauss's "Video" and de Man's 1969 essay "The Rhetoric of Temporality": both read moments of a fall and turn to the question of language in order to consider mirroring, doubling, and the reflective activity that delineates the self from the empirical world.

De Man takes his inspiration from Baudelaire's "De l'essence du rire" to develop the concept of an "ironic consciousness." Despite everyone's cordial assurances to the contrary, it would seem that our fears are in fact justified, for it is only the philosopher or the artist who has the capacity to "laugh with" instead of being "laughed at." Baudelaire writes:"It is least of all the falling man who is able to laugh at his own fall, unless he is a philosopher, a man who has acquired by habit the power to rapidly make himself double (se dédoubler) and to watch, as a disinterested spectator, the phenomenon of his 'me"' ("Ce n'est point l'homme qui tombe qui rit de sa propre chute, à moins quill ne soit philosophe, un homme qui ait acquis, par habitude, la force de se dédoubler rapidement et d'assister comme spectateur désintéressé aux phénomènes de son moi"). ${ }^{8}$ Doubling, or "ironic consciousness" then becomes the hallmark of reflective activity, "dédoublement as the characteristic that sets apart a reflective activity ... from that of the ordinary self caught in everyday concerns." The fall of Baudelaire's laughing philosopher enacts a suspension, through language, which"divides the subject into an empirical self, immersed in the world, and a self that becomes like a sign in its attempt at differentiation and self-definition."10 Language, as in Boomerang or in Lacanian analysis, points to the disjunction between the two laughing men, or the image on the camera and on the monitor. It disrupts the movement of "narcissism" by showing us that the self can never fully coincide with itself. The collapsed present of the fall is necessary to gain the knowledge of difference.

Significantly, Krauss's description of "feedback" is also one of a fall: "the feedback coil of video seems to be the instrument of a double repression: for through it consciousness of temporality and of separation between subject and object are simultaneously submerged. The result of this submergence is, for the maker and the viewer of most video-art, a kind of weightless fall through the suspended space of narcissism."11 Yet she, like de Man, points to the inevitable disjunction between the seamless and vertiginous but ultimately illusory 
autonomy of the subject in the instant of "ironic" or "narcissistic" perception. Where de Man turns to the double-nature of language (rhetoric), Krauss looks to the material or ab intra potential for disruption of the video medium and its ability to call attention to this disjunction, taking the work of Peter Campus as her example. She writes: "The narcissistic enclosure inherent in the video-medium becomes for him part of a psychologistic strategy by which he is able to examine the general conditions of pictorialism in relation to its viewers. It can, that is, critically account for narcissism as a form of bracketing-out the world and its conditions, at the same time as it can reassert the facticity of the object against the grain of the narcissistic drive towards projection."12 The narcissistic aesthetics of video become then necessary to distinguish and determine difference.

The boundaries between subject and object must here be maintained and guarded against the dangers of projection by the disruption of their seamless quality (or, to draw from Laura Mulvey, the erasure of their marks of production) and to reinsert them into the materiality of production. ${ }^{13}$ The medium disrupts itself in Krauss's description of video and allows for it to be ambiguously reflective and narcissistic. Like de Man's description of the laughing philosopher, it is the ironic consciousness of that which mediates our immediate experience that enables the recognition of pure autonomy or subjectivity as a delusion. If we are to consider the aesthetics of screendance, the sensory experiences or the encounters it makes available, we must also consider the screen, the glass pane of language, which enables, disrupts, and circulates the narcissistic encounter. "How can we know the dancer from the dance," asked Yeats? ${ }^{14}$ By looking at the screen.

\section{References}

de Man, Paul. Blindness and Insight: Essays in the Rhetoric of Contemporary Criticism. $2^{\text {nd }}$ edition. Minneapolis: University of Minnesota Press, 1983.

Krauss, Rosalind. "Video: The Esthetics of Narcissism." October 1 (1976): 50-64.

Rancière, Jacques. Aesthetics and Its Discontents. Translated by Steven Corcoran. Malden, MA: Polity Press, 2009.

Rosenberg, Douglas. "Proposing a Theory of Screendance." Paper presented at the American Dance Festival, Duke University, Durham, North Carolina, July 6-9, 2006.

Yeats, W.B. "Among School Children." The Yeats Reader. Edited by Richard J. Finneran. Revised edition. New York: Scribner Poetry, 2002.

\section{Notes}

1. Rosenberg, "Proposing a Theory of Screendance."

2. Rancière, Aesthetics, 2.

3. Krauss, "Video," 59.

4. Rosenberg, "Proposing."

5. Krauss, 59

6. Ibid., 57.

7. de Man, Blindness and Insight, 211.

8. Ibid., (translation mine). Charles Baudelaire, "De l'essence du rire,"in Curiosités esthétiques: L'art romantique et autres œuvres critiques, edited by H. Lema"tre (Paris: Garnier, 1962), 215, quoted in de Man, 211-12.

9. Ibid.

10. Ibid., 213

11. Krauss, "Video," 58-59.

12. Ibid, 64.

13. Rosenberg calls our attention to the tension between screendance and the market and mainstream distribution, drawing from Mulvey's work: "In her book from 1996, Fetishism and Curiosity, Laura Mulvey explains, from a Marxist point of view that,'a commodity's market success depends on the erasure of the marks of production', allowing commodity fetishism to 'triumph as spectacle."' (Rosenberg, "Proposing a Theory of Screendance.")

14. W.B. Yeats, "Among School Children," 105. 